\title{
COMMENT
}

\section{DISCLOSURE OF PRIOR STATEMENTS OF A GOVERNMENT WITNESS IN FEDERAL CRIMINAL PROSECUTIONS}

Defendants in federal criminal prosecutions who seek prior statements of government witnesses from government files for the purpose of impeachment ${ }^{1}$ have encountered the assertion of a congressionally authorized privilege. ${ }^{2}$ While recognizing the importance of non-disclosure to law. enforcement agencies, particularly in the area of subversive activities, courts have been prompted by considerations of fairness to order limited disclosure. Failure to comply with such an order has been said to require dismissal of the prosecution..$^{3}$ Until recently the law has been unsettled as to (1) the basis for ordering disclosure, (2) the procedural requirements necessary to acquire an order for disclosure and (3) the extent of the disclosure required.

In those cases in which production of witness' statements have been required, ${ }^{4}$ the bases for ordering disclosure have varied. Some courts have claimed that institution of a criminal action constitutes waiver or abandonment of the privilege, ${ }^{5}$ while others have asserted that it is un-

1. The courts have agreed that the witness' statements can be used only to impeach. Fryer v. United States, 207 F.2d 134 (D.C. Cir.), cert. denied, 346 U.S. 885 (1953) ; United States v. Brown, 17 F.R.D. 286, 288 (N.D. I1l. 1955) ; Únited States v. Bell, 126 F. Supp. 612, 617-18 (D.D.C. 1955). Under UNIForM RULES of EvidenCE rule $63(1)$ the statements would be admissible substantively as well as for impeachment.

2. REv. STaT. $\$ 161$ (1875), 5 U.S.C. $\$ 22$ (1952). This statute provides that "the head of each department is authorized to prescribe regulations, not inconsistent with law, for ... the custody, use, and preservation of the records, papers, and property appertaining to [the department]." Pursuant to this statute, the Attorney General has promulgated regulations forbidding his subordinates to turn over any document in department files without his approval: Order no. 3229, 28 C.F.R. \$ 51.71 (Supp. 1946), as amended and supplemented, PIKE \& FisceER AD. L. (2d ser.) Department of Justice 1-2. The Supreme Court held that a subordinate cannot be held in contempt for following these regulations, United States ex rel. Touhy v. Ragen, 340 U.S. 462 (1951), but refused to consider "the ultimate reach of the authority of the Attorney General to refuse to produce .... the government papers .... [since he] was not before the trial court." Id. at 467 . See Timbers \& Cohen, Demands of Litigants for Government Information, 18 U. PIrr. L. REv. 687 (1957).

3. United States v. Grayson, 166 F.2d 863, 870 (2d Cir. 1948); United States v. Andolschek, 142 F.2d 503, 506 (2d Cir. 1944) (by implication).

4. Disclosure is not unique to criminal actions. It has also been ordered where the Government is plaintiff in a civil suit. United States v. Cotton Valley Operators Comm., 9 F.R.D. 719 (W.D. La. 1949), aff'd by an equally divided court, 339 U.S. 940 (1950). Where the Government is a party defendant disclosure will apparently not be ordered, United States v. Reynolds, 345 U.S. 1, 12 (1953) (dictum), nor in a federal proceeding in which the Government is not a litigant, United States ex rel. Touhy v. Ragen, 340 U.S. 462 (1951), nor in a state proceeding, Parsons v. State, 251 Ala. 467,38 So. $2 d 209$ (1948).

5. E.g., United States v. Beekman, 155 F.2d 580 (2d Cir. 1946); United States v. Krulewitch, 145 F.2d 76 (2d Cir. 1944). 
conscionable to undertake prosecution and then invoke the privilege to deprive defendant of possible exculpatory information. ${ }^{b}$ Further uncertainty has existed with respect to the procedural requirements necessary to acquire an order for production of the documents. When defendant has sought direct access to the witness' statements, many courts have required a showing of contradiction between the witness' testimony and the statements. $^{7}$ Other cases have rested disclosure in the discretion of the trial judge. ${ }^{8}$ The Second Circuit has adhered to the practice of requiring the Government to submit requested statements to the trial court for examination in camera, ${ }^{9}$ the court being obligated to turn over to the defendant any statements admissible for the purpose of impeachment. ${ }^{10}$ The final problem, the portion of the official documents required to be disclosed to

6. E.g., United States v. Reynolds, 345 U.S. 1, 12 (1953) (dictum) ; United States ex rel. Schlueter v. Watkins, 67 F. Supp. 556, 561 (S.D.N.Y. 1946) (dictum) ; Berger \& Krash, Government Immunity From Discovery, 59 Y YLE I.J. 1451, 1453-54 (1950).

A few courts have suggested that the sixth amendment requires disclosure. United States v. Schneiderman, 106 F. Supp. 731 (S.D. Cal. 1952); Christoffel v. United States, 200 F.2d 734 (D.C. Cir.) (dictum), rev'd on other grounds, 345 U.S. 947 (1952). The portion of the sixth amendment invoked in such cases is that which affords to the accused the right "to have compulsory process for obtaining witnesses in his favor. . . ."U.S. Consr. amend. VI.

7. In Gordon v. United States, 344 U.S. 414 (1953), the Court required disclosure where the defendant had shown, inter alia, contradiction. This was interpreted to mean that the defendant was required to show contradiction before he could inspect that statement, e.g., Herzog v. United States, 226 F.2d 561 (9th Cir. 1955); Scanlon v. United States, 223 F.2d 382 (1st Cir. 1955). Cf. United States v. Bookie, 229 F.2d 130 (7th Cir. 1956) (defendant sought to see prior statements of his own witness). But see Fisher v. United States, 231 F.2d 99 (9th Cir. 1956). In Jencks v. United States, 353 U.S. 657 (1957), the Court said that Gordon, supra, had not meant to imply that a showing of contradiction was a prerequisite. Id. at 667 .

8. E.g., Goldman v. United States, 316 U.S. 129 (1942) (this case apparently has been overruled by the Jencks case); d'Aquino v. United States, 192 F.2d 338 (9th Cir. 1951), cert. denied, 343 U.S. 935 (1952); Kaufman v. United States, 163 F.2d 404 (6th Cir. 1947).

9. E.g., United States v. Cohen, 145 F.2d 82 (2d Cir. 1944), cert. denied, 323 U.S. 799 (1945); United States v. Krulewitch, 145 F.2d 76 (2d Cir. 1944); Note, 41 CoRNEIL L.Q. 737 (1956).

10. In those courts adhering to the Second Circuit practice, failure by the trial judge to disclose contradictory statements to the defendant has required reversal of the conviction. Scales v. United States, 227 F.2d 581 (4th Cir. 1955), cert. granted, 350 U.S. 992 (1956) ; United States v. Lebron, 222 F.2d 531 (2d Cir. 1955); Shelton v. United States, 205 F.2d 806 (5th Cir.), cert. dismissed, 346 U.S. 892 (1953). Where the issue has been raised, it is clear that failure to disclose any impeaching matter is sufficient to require reversal. United States v. Beekman, 155 F.2d 580 (2d Cir. 1946) (evidence of bias).

A similar diversity of views exists in the states. Some courts require a showing of contradiction. Rosier v. People, 126 Colo. 82, 247 P.2d 448 (1952) ; People v. Moses, 142 N.E.2d 1 (IIl. 1957). But see People v. Riser, 47 Cal.2d 566, 305 P.2d 1 (1956). Other courts have rested discretion in the trial judge. State v. Pembianchi, 139 Conn. 543, 95 A.2d 695 (1953) ; Commonwealth v. Galvan, 323 Mass. 205, 80 N.E.2d 825 (1948); see also FlA. STAT. ANN. \& 909.18 (1944). A few courts have refused any disclosure. State v. Arnold, 84 Mont. 348, 275 Pac. 757 (1929) ; State v. Thomasson, 97 N.E.2d 42 (Ohio App. 1950). The basis for this result seems to be a "reciprocity" theory; since the defendant may avail himself of the privilege against self-incrimination to conceal relevant matter, the prosecution should have a reciprocal privilege. State v. Bunk, 63 A.2d 842, 844 (N.J. 1949). For a criticism of this theory, see Comment, Pre-Trial Disclosure in Criminal Cases, 60 YALE, L.J. 626, 634-35 (1951). 
the defendant, had not been clearly articulated by the Supreme Court until its recent decision in Jencks $v$. United States. ${ }^{11}$

In the Jencks case, petitioner, a labor union official, was convicted of making false statements in a non-communist affidavit filed pursuant to section $9(\mathrm{~h})$ of the Taft-Hartley Act.12 Two of the government witnesses had been members of the communist party during the time it was alleged petitioner had been a member, and had reported to the Federal Bureau of Investigation concerning petitioner's activities. At the trial, his counsel sought production of these reports for examination by the trial judge and delivery to the defendant of such of them as he found relevant. The trial judge denied the motion and the circuit court affirmed. ${ }^{13}$ On appeal, the Government urged that in the absence of a showing of contradiction the reports were privileged against disclosure under the rules of the Department of Justice. ${ }^{14}$ The Supreme Court reversed ${ }^{15}$ holding that petitioner, without showing contradiction, ${ }^{16}$ was entitled to inspect the witness' statements 'touching the events and activities as to which [the witnesses] testified at the trial." 17 Further, the practice of producing the statements first to the trial judge was disapproved; the Court directed that the trial judge's determination of the admissibility of any portion of the report could be made only after inspection by the defendant.18

By indicating that the function of the trial judge was limited to a determination of the admissibility of a witness' statement after production and

11. 353 U.S. 657 (1957). The Second Circuit, until the Jencks case, has been uniform in requiring disclosure of only those portions of a witness' statements which would be admissible to impeach him. See cases cited in note 9 supra. Other circuits, not following the Second Circuit rule, have not stated the extent of the disclosure required.

12. 61 STAT. 146 (1947), 29 U.S.C. \& 159(h) (1952).

13. 226 F.2d 540 (5th Cir. 1955). The court of appeals held that the defendant must make a prior showing of contradiction, relying on Shelton v. United States, 205 F.2d 806 (5th Cir.), cert. dismissed, 346 U.S. 892 (1953). However, it would appear that the court's reliance was misplaced since in that case the trial judge had examined the statement and the court held he need not turn it over to the defendant unless he found a contradiction. Id. at 814 .

14. See note 2 supra.

15. Justices Burton and Harlan concurred on another ground. Justice Clark dissented and Justice Whittaker did not participate.

16. See note 7 supra.

17. 353 U.S. at 668 . The Court indicated that sufficient limits on the defendant's request for production were provided by the distinction between a "blind fishing expedition" and a demand for specific documents. $I d$. at 667. Although such a distinction would be applied on a case to case basis by the trial judge, errors on his part could not be enforced by the Government. Assuming the trial judge granted a demand, if the Government elected not to produce, its case would be dismissed. If it did produce the statements and a verdict of acquittal was rendered, the Government could not appeal. Finally, if it produced the statements and still won a conviction, the defendant on appeal would hardly raise the issue.

18. "The practice of producing government documents to the trial judge for his determination of relevancy and materiality, without hearing the accused, is disapproved. Relevancy and materiality for the purposes of production and inspection, with a view to use on cross-examination, are established when the reports are shown to relate to the testimony of the witness. Only after inspection of the reports by the accused, must the trial judge determine admissibility-e.g., evidentiary questions of inconsistency, materiality and relevancy - of the contents and the method to be employed for the elimination of parts immaterial or irrelevant." Id. at 669. 
examination by the defendant, the Court left unclarified the problem of whether portions of a witness' statement, even though unrelated to his testimony, could be excised from the report prior to examination by the defendant. ${ }^{19}$ In prosecutions pending at the time of the decision lower federal courts reached sharply conflicting results on the issue. ${ }^{20}$ This diversity in application of the Jencks decision ${ }^{21}$ fomented the enactment of congressional legislation. ${ }^{22}$ The statute reasserts the holding of the

19. "We now hold that petitioner was entitled to an order directing the Government to produce for inspection all reports ... touching the events and activities as to which [the witnesses] testified at the trial." $I \dot{d}$. at 668 .

20. [Unless otherwise cited, the following cases are taken from a brief printed in 103 CoNG. Ric. $14551-54$ (daily ed. Aug. 26, 1957)].

Several cases held that the Government must produce an entire investigative report. E.g., United States v. Stanley (N.D. Ga.) (the court held that the Government could not delete nonrelevant portions); United States v. Erie Co. Malt Beverage Dist. Ass'n (W.D. Pa.); United States v. Young (S.D. Tex.) (122 documents; defense counsel called government attorney the day after the order and said "Mail them to me"). Contra, United States v. Anderson (E.D. Mo.). See also United States v. Rosenburg, Crim. No. 12,209, 3d Cir., June 26, 1957, reversing, 146 F Supp. 555 (E.D. Pa. 1956). Compare Simms v. United States, 26 U.S.L. WeEr 2028 (D.C. Cir. July 8, 1957) (held that the Jencks case does not require disclosure where the defense sought the requested statements to show the criminal record of the witness), with United States v. Beekman, 155 F.2d 580 (2d Cir. 1946) (the court, prior to Jencks, held it reversible error for the trial judge not to read the statements to see if they contained data showing previous disciplining of the witnesses).

It was held that the Jencks decision guarantees the defendant a right to inspect the statements of potential government witnesses at pretrial. United States v. Hall, 26 U.S.L. WEEK 2060 (W.D. Ky. July 22, 1957) (the agent-in-charge of the local office of the Federal Bureau of Investigation, under orders from Attorney General Brownell, refused to produce the statements. The court insisted that the trial continue and held the agent in contempt of court under a fine of $\$ 1,000$. Christian Science Monitor, Aug. 14, 1957, p. P(R), col. 4. Contra, United States v. Palermo, New York Times, Aug. 27, 1957, p. 24, col. 3; United States v. Grossman, 26 U.S.L. WEEK 2060 (D.N.J. July

$12,1957)$; United States v. Benson, 25 U.S.L. WEEK 2603 (S.D.N.Y. June 17, 1957).

21. See note 20 supra.

22. Pub. L. No. 85-269, 85th Cong., 1st Sess. $\S 3500$ (Sept. 2, 1957). The relevant parts of the statute provide: "(a) In any criminal prosecution brought by the United States, no statement or report in the possession of the United States which was made by a Government witness ... shall be the subject of ... discovery ... until said witness has testified on direct examination. ... (b) After a witness called by the United States has testified on direct examination, the court shall, on motion of the defendant, order the United States to produce any statement ... of the witness in the possession of the United States which relates to the subject matter as to which the witness has testified. If the entire contents of any such statement relate to the subject matter of the testimony of the witness, the court shall order it to be delivered directly to the defendant for his examination and use. (c) If the United States claims that any statement ordered to be produced under this section contains matter which does not relate to the subject matter of the testimony of the witness, the court shall order the United States to deliver such statement for the inspection of the court in camera. Upon such delivery the court shall excise the portions of such statement which do not relate to the subject matter of the testimony of the witness. With such material excised, the court shall then direct delivery of such statement to the defendant for his use. If, pursuant to such procedure, any portion of such statement is withheld from the defendant and the defendant objects to such withholding, and the trial is continued to an adjudication of the guilt of the defendant, the entire text of such statement shall be preserved by the United States and, in the event the defendant appeals, shall be made available to the appellate court for the purpose of determining the correctness of the ruling of the trial judge. ... (d) If the United States elects not to comply with an order of the court under paragraph (b) or (c) hereof to deliver to the defendant any such statement, or such portion thereof as the court may direct, the court shall strike from the record the testimony of the witness, and the trial shall proceed unless the court in its discretion shall determine that the interests of justice require that a mistrial be declared." 
Jencks case that the defendant is entitled to prior statements of a government witness which relate "to the subject matter as to which the witness has testified." 23 If the Government claims, however, that a statement contains matter which is not relevant, the statement is to be produced for examination by the trial judge in camera who will excise irrelevant material. ${ }^{24}$ The statute further provides a procedure for correcting errors by the trial judge on appeal..$^{25}$

By clarifying the position of the trial judge, the statute insures that only relevant material will be turned over to the defendant, a matter left uncertain by the Jencks decision. ${ }^{26}$ Furthermore, rejection by the statute of the Second Circuit view, ${ }^{27}$ which limits disclosure to statements found by the judge in an ex parte determination to be admissible for the purposes of impeachment, ${ }^{28}$ appears sound. The trial judge does not have the same insight into the facts as do the parties so as to be aware of all that might impeach. By permitting the defendant to inspect all factually relevant statements and by having the trial judge hear both parties on relevance for admissibility, the danger of impeaching evidence passing unnoticed is diminished. On the other hand, ordering disclosure of all factually relevant information may result in disclosure of a greater amount of matter vital to national security. ${ }^{29}$ Apparently, both the Court in Jencks and Congress in enacting the statute prefer the interest of the defendant in this matter. The penalty on the Government for non-disclosure, however, is lessened by the provision in the statute that in the event of failure of the Government to comply with a disclosure order, the judge has discretion either to strike the testimony of the witness or to declare a mistrial. ${ }^{30}$ It would seem that in view of the protection afforded the defendant, the balance struck by the statute is reasonable.

It is in connection with privileges other than the statutory privilege applying generally to governmental documents that the statute may have its greatest impact, although perhaps unwittingly so. While the decision in the Jencks case is limited by its facts (a prior statement of a witness,

\section{Ibid.}

24. Ibid.

25. If the trial results in conviction, the Government is to preserve the statement and, if the defendant appeals, make it available to the appellate court for its inspection.

26. See text and notes at notes 19-20 supra.

27. Jencks similarly rejected this view. See text and note at note 18 supra.

28. See text and notes at notes 9-10 supra.

29. Besides the statutory privilege, two common-law privileges-the privilege protecting the names of informers and that protecting state secrets-have served to bar disclosure of a certain amount of information in government files vital to national security. The state secret privilege, for example, would protect evidence involving military affairs or concerning international relations, but neither would probably protect such matters as investigative techniques of the Federal Bureau of Investigation or information it collects on subversive activities. See Hoover, The Confidential Nature of FBI Reports, 8 SYR. L. REV. 2 (1956). Therefore, constriction of the statutory privilege will have the possible effect of revealing a greater amount of security information.

30. Pub. L. No. 85-269, 85th Cong., 1st Sess. \$ 3500 (Sept. 2, 1957). In this context, the judge cannot hold in contempt governmental officials refusing to comply with an order for production. Cf. note 20 supra. 
privileged under departmental regulations, and not used by the witness on the stand), the statute admits no such limitation. It seems clear that the hitherto prevailing view on disclosure of privileged statements of a witness used to refresh his recollection, which rested disclosure in the discretion of the trial judge, ${ }^{31}$ has been nullified. More significant is the statute's applicability to the privilege against disclosure of the names of informers, ${ }^{32}$ with reference to which the Supreme Court has said that "no fixed rule with respect to disclosure is justifiable" 33 and that the problem is one "that calls for balancing the public interest in protecting the flow of information against the individual's right to prepare his defense." 34 Similarly effected is the common-law privilege for state secrets which is independent of statutory regulations and exists for information "involving the public security or concerning the military organization or plans of the United States . . . or concerning international relations." 35 Under the statute, if any of these privileges are involved in a report by a government witness, the trial judge must, nevertheless, order disclosure of the material so long as it is factually relevant, ${ }^{36}$ regardless of countervailing considerations. If the Government elects not to produce the documents, the testimony of the witness will be stricken or the judge in his discretion, may declare a mistrial. ${ }^{37}$ Because the present formula would seem to endanger a considerable amount of information vital to national security and because it is not clear that Congress intended to impinge upon the common-law privileges, it is suggested that Congress reconsider the problem with a view toward clarifying its intent.

31. United States v. Socony-Vacuum Oil Co., 310 U.S. 150, 231-37 (1940).

32. 8 WIGMORE, EVIDENCE $§ 2374$ (3d ed. 1940).

33. Roviaro v. United States, 353 U.S. 53, 62 (1957).

34. Ibid.

35. UNIForar Rutes of Evidence rule 33. See also 8 Wigmore, Evidence $\$ 2378$, at 785 (3d ed. 1940).

36. See text and notes at note 22 and note 23 silpra.

37. See text and note at note 30 supra. 